\title{
PENGARUH PENERAPAN SKS, MOTIVASI EKSTRINSIK, DAN DISIPLIN BELAJAR TERHADAP PRESTASI BELAJAR EKONOMI SISWA KELAS XI IPS SMAN 3 PURWOKERTO
}

\author{
Ikke Iryanti ${ }^{*}$, Ratno Purnomo² \\ 1,2, Fakultas Ekonomi dan Bisnis, Universitas Jenderal Soedirman, Indonesia \\ *Email corresponding author : iryantiikke8@gmil.com
}

\begin{abstract}
Abstrak
Tujuan penelitian adalah untuk menganalisis pengaruh penerapan SKS, motivasi ekstrinsik, dan disiplin belajar terhadap prestasi belajar ekonomi kelas XI IPS SMAN 3 Purwokerto. Penelitian ini menggunakan pendekatan kuantitatif dengan metode survey. Populasi penelitian ini adalah seluruh siswa kelas XI SMAN 3 Purwokerto. Untuk menganalisis hipotesis menggunakanan anlisis regresi linier berganda. Kesimpulannya yaitu : 1. Penerapan Sistem Kredit Semester (SKS) tidak berpengaruh secara signifikan terhadap prestasi belajar ekonomi siswa kelas XI IPS SMAN 3 Purwokerto; 2. Motivasi ekstrinsik berpengaruh positif terhadap prestasi belajar ekonomi siswa kelas XI IPS SMAN 3 Purwokerto; 3. Disiplin belajar berpengaruh positif terhadap prestasi belajar ekonomi siswa kelas XI IPS SMAN 3 Purwokerto; 4. Disiplin belajar memiliki pengaruh yang paling dominan terhadap prestasi belajar ekonomi siswa kelas XI IPS SMAN 3 Purwokerto.
\end{abstract}

Kata Kunci : SKS, Motivasi Ekstrinsik, Disiplin, Prestasi.

\begin{abstract}
The purpose of the study was to analyze the effect of applying SKS, extrinsic motivation, and learning discipline on economic learning achievement in class XI IPS SMAN 3 Purwokerto. This research uses a quantitative approach with a survey method. The population of this research was all students of class XI of SMAN 3 Purwokerto. To analyze hypotheses using multiple linear regression analysis. The conclusions are: 1. The application of the Semester Credit System (SKS) does not significantly influence the economic learning achievement of students of class XI IPS SMAN 3 Purwokerto; 2. Extrinsic motivation has a positive effect on students' economic learning achievement in class XI IPS SMAN 3 Purwokerto; 3. Learning discipline has a positive effect on the economic learning achievement of students of class XI IPS SMAN 3 Purwokerto; 4. Learning discipline has the most dominant influence on students' economic learning achievement in class XI IPS SMAN 3 Purwokerto.
\end{abstract}

Keywords: SKS, Extrinsic Motivation, Discipline, Achievement.

\section{PENDAHULUAN}

Schroeder (2012) mengemukakan bahwa Sumber Daya Manusia (SDM) memiliki peranan dan kontribusi yang sangat penting dalam membantu meningkatkan kondisi perekonomian negara. Seiring dengan perkembangan kehidupan di era globalisasi, kualitas sumber daya manusia harus selalu ditingkatkan. Salah satu cara untuk meningkatkan kualitas SDM adalah melalui pendidikan. Kondisi pendidikan di Indonesia saat ini cukup memprihatinkan, OECD (2016) hal ini dibuktikan dengan laporan PISA (Programme For International Students Assesment) tahun 2015 menyatakan bahwa kualitas sistem pendidikan Indonesia menempati posisi ke 62 dari 72 negara. Sumantri (2010) mengemukakan bahwa masalah pendidikan Indonesia disebabkan oleh beberapa faktor yaitu belum tumbuhnya kesadaran gemar belajar, ketidaksetaraan pendidikan yang ada di Indonesia serta kurang efektif dan efisiennya sistem penyajian materi pembelajaran. 
Pemerintah Indonesia melalui kementerian terkait sampai saat ini masih melakukan berbagai upaya perbaikan-perbaikan, guna meningkatkan mutu pendidikan yang lebih baik. Hasbullah (2013:123-125) mengemukakan yang dimaksud dengan sistem pendidikan adalah jumlah keseluruhan antar bagian yang saling bekerja sama untuk mencapai suatu tujuan berdasarkan kebutuhan yang telah ditetapkan. Secara umum tujuan pendidikan adalah untuk meningkatan kualitas sumber daya manusia seperti yang tertuang dalam UU Nomor 20 Tahun 2003 Pasal 3 tentang tujuan pendidikan nasional yang memiliki fungsi untuk mengembangkan kemampuan dan watak peserta didik serta peradaban bangsa yang bermartabat dalam rangka mencerdaskan kehidupan bangsa, selain itu pendidikan juga bertujuan untuk mengembangkan potensi peserta didik agar menjadi manusia yang beriman, berakhlak mulia serta berilmu, cakap, kreatif dan menjadi warga negara yang bertanggung jawab.

Tanpa adanya pendidikan akan sulit memperoleh kualitas sumber daya manusia secara maksimal. Salah satu upaya perbaikan yang dilakukan pemerintah untuk meningkatkan prestasi dan mutu pendidikan Indonesia adalah dengan penerapan Sistem Kredit Semester (SKS) di Sekolah Menangah Atas/ Aliyah dan juga Sekolah Menengah Pertama/ Madrasah. Hal tersebut telah diatur dalam panduan penyelenggaraan SKS, yang disusun oleh Badan Standar Nasional Pendidikan (BSNP) sesuai dengan kewenangan pemerintah yang diatur dalam peraturan pemerintah No. 15 Tahun 2005 tentang Standar Nasional Pendidikan. Tujuan penerapan SKS adalah agar para siswa dapat memilih dan menentukan secara mandiri bobot mata pelajaran yang akan di ambilnya. Dengan demikian siswa dapat menargetkan lulus dengan waktu kurang dari 3 tahun, penerapan SKS merupakan hasil dari perkembangan akselerasi. Pembelajaran SKS berbeda dengan sistem paket dimana dengan menggunakan SKS siswa dapat belajar secara lebih fleksibel dan variatif.

Pemilihan mata pelajaran pada Sistem Kredit Semester disesuaikan dengan bakat, minat serta kecepatan pemahaman siswa dalam menangkap materi pelajaran yang diberikan oleh guru dalam proses pembelajaran. Sebagian besar sekolah menengah pertama dan juga sekolah menengah atas yang ada di Indonesia saat ini masih menggunakan sistem paket, hal ini dirasa kurang demokratis karena kemampuan dari setiap siswa berbeda-beda dan tidak dapat disamaratakan. Anwar (2018) menyatakan bahwa SKS telah diterapkan oleh 144 sekolah diseluruh Indonesia, salah satunya di SMA Negeri 3 Purwokerto. Akan tetapi efek dari penerapan SKS ini belum diketahui, diharapkan dengan penerapan SKS ini dapat meningkatkan prestasi belajar siswa, yang dibuktikan dengan hasil skor dari hasil tes materi yang telah dipelajari.

Berdasarkan penelitian yang dilakukan oleh Muhlis (2017) membuktikan bahwa ada pengaruh positif dan signifikan proses pembelajaran menggunakan SKS terhadap prestasi belajar. Berbeda halnya dengan hasil penelitian yang dilakukan oleh Santoso (2015) bahwa 
tidak ada pengaruh signifikan atau negatif proses pembelajaran SKS terhadap prestasi belajar siswa. Suryabrata (2014:233) mengemukakan bahwa prestasi belajar dipengaruhi oleh beberapa faktor yaitu faktor internal dan faktor eksternal. Faktor internal terdiri dari fisiologis dan psikologis siswa. Faktor fisiologis seperti pendengaran, penglihatan dan stuktur tubuh. Sedangkan, faktor psikologis seperti kecerdasan, minat, bakat, disiplin belajar dan juga motivasi. Faktor eksternal terdiri dari lingkungan sosial dan lingkungan nonsosial. Lingkungan sosial seperti keluarga, masyarakat, lingkungan dan juga teman. Sedangkan, nonsosial seperti teknologi, fasilitas belajar dan iklim belajar dalam penelitian ini adalah Sistem Kredit Semester (SKS). Salah satu faktor yang dapat mempengaruhi prestasi belajar yaitu motivasi belajar. Uno (2009:4) motivasi belajar merupakan hal yang sangat penting bagi siswa, dengan memiliki motivasi belajar yang tinggi maka akan berdampak baik terhadap prestasi belajar. Aunurrahman (2010:115-116) mengemukakan bahwa motivasi dibagi menjadi dua macam, pertama motivasi yang timbul dari dirinya sendiri untuk melakukan aktivitas (intrinsik), contohnya siswa mempelajari pelajaran ekonomi dengan sungguh-sungguh karena terdorong untuk mendapatkan pengetahuan. Kedua motivasi yang timbul karena adanya pengaruh dari luar (ekstrinsik), contohnya siswa belajar dengan sungguh-sungguh karena dijanjikan hadiah oleh orang tua.

Hal ini sesuai dengan Azis (2017) menyatakan bahwa terdapat pengaruh positif antara motivasi ekstrinsik dengan prestasi belajar ekonomi, berbeda halnya dengan penelitian yang dilakukan oleh Aini (2016) bahwa tidak terdapat pengaruh yang signifikan antara motivasi ekstrinsik terhadap prestasi belajar siswa dalam mata pelajaran ekonomi. Selain motivasi belajar ekstrinsik dan SKS terdapat faktor lain yang mempengaruhi prestasi belajar, sebagaimana hasil penelitan terdahulu yang dilakukan Ma'sumah (2015) menemukan bahwa disiplin belajar dapat mempengaruhi prestasi belajar siswa dan Fatmawati (2012) yang membuktikan bahwa motivasi ekstrinsik dan disiplin belajar secara simultan berpengaruh positif dan signifikan terhadap prestasi belajar siswa. Slameto (2010:67) mengemukakan bahwa disiplin belajar mencakup kerajinan siswa dalam sekolah dan juga belajar dan mengikuti tata tertib yang diberlakukan.

Disiplin belajar membuat siswa lebih terarah dan terhindar dari rasa malas dan akan menumbuhkan semangat untuk belajar, disiplin belajar dapat dilakukan di sekolah dan di rumah. Siswa melaksanakan disiplin belajar di sekolah dengan cara aktif masuk sekolah, mentaati tata tertib sekolah, aktif dalam kegiatan proses pembelajaran dan mengerjakan tugas yang diberikan oleh guru. Siswa melaksanakan disiplin belajar di rumah dengan cara senantiasa belajar dengan teratur tanpa adanya paksaan dari orang lain, maka disiplin belajar dipandang sebagai faktor yang mempengaruhi prestasi belajar siswa. Hal ini dibuktikan dengan penelitian yang dilakukan oleh Sari et al. (2017) menyatakan bahwa terdapat pengaruh 
positif disiplin belajar terhadap prestasi belajar siswa. Berbeda halnya dengan hasil penelitian yang dilakukan oleh Setyaningrum (2011) membuktikan bahwa tidak ada pengaruh yang signifikan antara disiplin belajar dan prestasi belajar siswa.

Berdasarkan hasil observasi yang dilakukan peneliti di SMAN 3 Purwokerto telah terjadi penurunan rata-rata nilai rapor siswa pada mata pelajaran ekonomi di kelas XI IPS 3 yang tertera pada tabel 1 .

Tabel 1. Rata-rata Nilai Rapor Mata Pelajaran Ekonomi Kelas XI IPS

\begin{tabular}{ccc}
\hline Kelas & $2017-2018$ & $2018-2019$ \\
\hline XI IPS 1 & 78,28 & 80,65 \\
XI IPS 2 & 83,57 & 85,11 \\
XI IPS 3 & 86,06 & 84,00 \\
XI IPS 4 & 83,85 & 86,52 \\
XI IPS 5 & 81,70 & 85,36 \\
\hline
\end{tabular}

Sumber: Daftar Nilai Rapor SMA Negeri 3 Purwokerto Tahun 2017/2018 dan 2018/2019

Dilihat dari hanya satu kelas yang mengalami penurunan rata-rata nilai rapor siswa, membuktikan bahwa penerapan SKS di SMAN 3 Purwokerto sudah baik, tetapi belum diterapkan secara maksimal. Hal ini diperkirakan disebabkan karena adanya salah satu faktor penerapan sistem kredit semester yang belum dijalankan yaitu moving class. Penerapan moving class di Sekolah Menengah Atas sama dengan sistem moving class di perkuliahan, dimana siswa yang mendatangi guru di kelas. Hal ini bertujuan untuk meningkatkan kualitas dan efektifitas proses pembelajaran serta memaksimalkan fungsi kelas, menurut pihak sekolah penerapan moving class belum dapat dilaksanakan karena masih dalam tahap penyesuaian dan membuat waktu pembelajaran menjadi kurang efektif sehingga belum cocok diterapkan di SMAN 3 Purwokerto.

\section{TINJAUAN PUSTAKA DAN PERUMUSAN HIPOTESIS}

\section{Prestasi Belajar}

Arifin (2013:12) menyatakan bahwa hasil belajar dan prestasi belajar merupakan dua hal yang berbeda. Dariyo (2013:89) mengemukakan bahwa prestasi belajar adalah hasil yang diperoleh siswa setelah mengikuti tes atau ujian dalam suatu pelajaran tertentu. Hal ini sesuai dengan Tirtonegoro (2006:43) mengemukakan bahwa prestasi belajar merupakan tingkat keberhasilan siswa dalam mempelajari subjek materi yang dinyatakan dalam bentuk angka (nilai), huruf atau simbol lainnya.

Dariyo (2013:90) mengemukakan bahwa secara umum terdapat dua faktor yang mempengaruhi prestasi belajar siswa, yakni: (1) Faktor internal merupakan faktor yang sangat erat kaitannya dengan kondisi siswa berasal dari dalam diri siswa sendiri. Meliputi kesehatan fisik, psikologis, disiplin, motivasi, kondisi emosional, kebiasaan belajar dan juga kesehatan. (2) Faktor eksternal merupakan faktor yang berasal dari luar diri siswa/faktor lingkungan disekitar 
siswa, faktor eksternal terdiri atas lingkungan fisik/nonsosial ialah lingkungan yang berupa sarana prasarana yang tersedia di sekolah, teknologi dan iklim belajar. Lingkungan sosial adalah suasana psikologis dan sosial yang terjadi selama proses pembelajaran berlangsung didalam kelas. Lingkungan sosial adalah suasana interaksi antara siswa dengan orang tua dalam lingkungan keluarga.

\section{Penerapan Sistem Kredit Smester (SKS)}

Zafar et al. (2014) mengemukakan bahwa Sistem Kredit Semester merupakan sistem pembelajaran yang fleksibel dan menarik. Dalam pelaksanaannya SKS berbeda dengan sistem paket, dimana siswa diberi kesempatan untuk menentukan sendiri jumlah beban belajar dan materi pembelajaran yang akan diikuti dalam satu semester. Hal ini sesuai dengan Musta'in et al. (2017) menyatakan bahwa pemilihan mata pelajaran siswa dalam satu semester dipilih dengan mempertimbangkan potensi, minat dan kinerja akademik yang dimilikinya.

Sistem Kredit Semester dirancang untuk memperluas cakupan kulikuler siswa dan tingkat kedalaman studi dalam mata pelajaran tertentu. Yoga et al. (2016) menyatakan bahwa bagi siswa yang memiliki prestasi tinggi dapat menyelesaikan studi lebih cepat. Sesuai dengan Undang-undang Nomor 20 tahun 2003 mengamatkan bahwa setiap peserta didik pada setiap satuan pendidikan berhak menyelesaikan program pendidikan sesuai dengan kecepatan belajar masing-masing.

Mengacu pada Badan Standar Nasional Pendidikan (BSNP) (2010:6) adapun prinsip dari penyelenggaraan sistem kredit semester di sekolah terdiri dari 9 poin yaitu: (1) Peserta didik menentukan sendiri mata pelajaran pada setiap semester. (2) Peserta didik dengan kemampuan yang tinggi dapat mempersingkat masa studi. (3) Peserta didik dituntut belajar mandiri. (4) Peserta didik mengatur sendiri strategi belajar agar menjadi lebih fleksibel. (5) Peserta didik diberi kesempatan untuk memilih pelajaran sesuai dengan potensi yang dimiliki. (6) Peserta didik dapat pindah ke sekolah di daerah lain yang telah menerapkan SKS. (7) Sumber daya pendidikan yang disediakan sekolah menjadi lebih memadai. (8) Kegiatan belajar di sekolah dapat lebih mengembangkan potensi yang dimiliki peserta didik. (9) Guru memfasilitasi semua kebutuhan akademik peserta didik.

\section{Motivasi Ekstrinsik}

Santrock (2011:514) mengemukakan bahwa motivasi ekstrinsik adalah melakukan sesuatu untuk mendapatkan sesuatu (insentif). Hal ini sesuai dengan Hamalik (2008:163) menyatakan bahwa motivasi ekstrinsik adalah usaha siswa untuk belajar lebih giat, yang disebabkan oleh beberapa faktor yang berasal dari luar situasi belajar seperti untuk mendapatkan nilai yang tinggi, tingkatan hadiah dan pujian. 
Terdapat beberapa faktor motivasi ekstrinsik menurut Slameto (2010:71) sebagai berikut: (1) Kondisi lingkungan dapat mempengaruhi motivasi belajar siswa, lingkungan ini terdiri dari tiga yaitu lingkungan keluarga, lingkungan sekolah dan lingkungan masyarakat. (2) Alat pelajaran yang digunakan erat kaitannya dengan cara belajar siswa, hal ini juga dapat membantu siswa menerima materi pelajaran yang diajarkan. (3) Penggunaan metode mengajar yang tepat dan baik akan berpengaruh terhadap meningkatnya motivasi belajar siswa begitupun sebaliknya.

\section{Disiplin Belajar}

Haryono (2016) disiplin adalah keadaan sikap atau perilaku seseorang yang sesuai dengan aturan atau tata tertib yang berlaku sehingga tercipta ketertiban dan keteraturan. Sumantri (2010) mengemukakan bahwa dengan memiliki disiplin belajar yang baik dapat meningkatkan prestasi belajar siswa di sekolah. Sesuai dengan Blegur et al. (2018) menyatakan bahwa disiplin belajar membuat siswa lebih patuh dan bertanggung jawab untuk menyelesaikan tugas sekolah. Sriyono (2017) mengemukakan bahwa disiplin belajar harus ditanamkan sejak dini, karena dengan adanya disiplin belajar dapat membantu siswa mengembangkan rasa tanggung jawab mengenai pentingnya belajar sehingga hasil belajar yang diperoleh menjadi lebih maksimal.

Terdapat beberapa faktor disiplin belajar menurut Sumantri (2010) sebagai berikut: (1)Faktor Fisiologis; Kesehatan siswa dapat membantu terlaksananya ketertiban dalam suasana proses pembelajaran berlangsung dengan tenang sehingga dapat meningkatkan prestasi siswa.(2) Faktor Perorangan; Setiap siswa memiliki sifat yang beragam seperti egois, acuh tak acuh bahkan mengganggu orang lain. Jika hal tersebut tidak diperhatikan dan dibiarkan maka akan mengganggu proses berlangsungnya pembelajaran karena tidak kondusif hal ini akan berpengaruh terhadap prestasi belajar. (3) Faktor Sosial; Sikap seseorang juga dipengaruhi oleh keadaan lingkungan sekitar, pengaruh tersebut antara lain: ingin bebas bertindak, ingin terpandang dan ingin tergabung dalam suatu kelompok.

\section{Pengaruh Sistem Kredit Semester Terhadap Prestasi Belajar Siswa Pada Mata Pelajaran Ekonomi Kelas XI IPS SMA Negeri 3 Purwokerto.}

Sistem kredit semester adalah satuan yang digunakan untuk menyatakan besarnya beban studi siswa, Mulyasana (2012:152) mengemukakan bahwa ketentuan mengenai beban belajar, jam pembelajaran, waktu efektif untuk tatap muka dan presentase beban belajar setiap kelompok mata pelajaran ditetapkan dengan peraturan menteri berdasarkan BSNP.

Sistem Kredit Semester berbeda dengan pembelajaran yang menggunakan sistem paket, dengan adanya SKS siswa dapat menentukan sendiri bobot mata pelajaran yang akan diambil 
sesuai dengan kemampuan, bakat dan juga minat siswa tersebut. Moestofa (2018) mengemukakan bahwa pengembangan dan penerapan SKS pada kurikulum 2013 ini sangat cocok, membuat siswa mendapatkan layanan sesuai dengan kemampuannya. Sehingga proses pembelajaran menjadi lebih efektif dan siswa belajar lebih aktif dan hal ini akan berpengaruh terhadap prestasi belajar.

Hasil penelitian yang dilakukan oleh Moesthafa (2018) terhadap siswa di SMA Negeri 1 Probolinggo membuktikan bahwa terdapat pengaruh positif antara penerapan sistem kredit semester dalam meningkatkan prestasi belajar siswa, Anjarsari (2017) mengemukakan bahwa sistem kredit semester dapat meningkatkan prestasi belajar, Hardini (2016) membuktikan bahwa terdapat pengaruh positif sistem kredit semester dengan prestasi belajar siswa. Sejalan dengan Zafar et al. (2014) yang mengemukakan bahwa Fully Flexible Credit System (FFCS) memiliki pengaruh yang tinggi terhadap prestasi belajar siswa.

Berdasarkan telaah pustaka dan penelitian terdahulu, maka peneliti tertarik untuk meneliti secara langsung dengan hipotesis sebagai berikut:

$\mathrm{H}_{1}$ : Sistem Kredit Semester Berpengaruh Positif Terhadap Prestasi Belajar Siswa Pada Mata Pelajaran Ekonomi Kelas XI IPS SMA Negeri 3 Purwokerto.

\section{Pengaruh Motivasi Ekstrinsik Terhadap Prestasi Belajar Siswa Pada Mata Pelajaran Ekonomi Kelas XI IPS SMA Negeri 3 Purwokerto.}

Hamalik (2008:163) motivasi ekstrinsik adalah motivasi yang disebabkan oleh faktor yang berasal dari luar situasi belajar seperti nilai, tingkatan hadiah, hukuman dan persaingan. Dengan adanya motivasi mampu meningkatkan semangat belajar siswa yang akan berpengaruh terhadap prestasi belajarnya.

Motivasi ekstrinsik adalah motivasi yang berasal dari luar salah satu contohnya adalah pengaruh dari lingkungan sekitar siswa mulai dari lingkungan sekolah seperti metode mengajar yang digunakan pendidik dalam melaksanakan kegiatan pembelajaran, memberi bimbingan serta pengarahan terhadap siswa dan menghargai pemikiran juga pendapatnya akan membuat motivasi belajar siswa meningkat. Lingkungan keluarga seperti memberikan pujian atau hadiah jika siswa mendapat nilai yang tinggi hal ini akan sangat berpengaruh terhadap motivasi belajar siswa.

Hasil penelitian yang dilakukan oleh Azis (2017) terdapat pengaruh positif dan signifikan antara motivasi ekstrinsik dengan prestasi belajar ekonomi. Sejalan dengan Octora (2013) mengemukakan bahwa motivasi ekstrinsik berpengaruh positif dan signifikan terhadap prestasi belajar mahasiswa, selanjutnya penelitian yang dilakukan oleh Sahiu dan Wijaya (2017) 
menunjukan motivasi ekstrinsik memiliki pengaruh yang positif bagi siswa yang ingin meningkatkan hasil belajarnya.

Berdasarkan telaah pustaka dan hasil dari penelitian terdahulu, maka peneliti tertarik untuk meneliti secara langsung dengan hipotesis sebagai berikut:

$\mathrm{H}_{2}$ : Motivasi Ekstrinsik Berpengaruh Positif Terhadap Prestasi Belajar Siswa Pada Mata Pelajaran Ekonomi Kelas XI IPS SMA Negeri 3 Purwokerto.

\section{Pengaruh Disiplin Belajar Terhadap Prestasi Belajar Siswa Pada Mata Pelajaran Ekonomi Kelas XI IPS SMA Negeri 3 Purwokerto.}

Disiplin dan mentaati berbagai peraturan di sekolah merupakan hal yang sangat penting bagi seorang siswa, hal ini dapat menciptakan suasana belajar yang tertib dan nyaman. Sumantri (2010) mengemukakan bahwa disiplin yang baik ketika membuat siswa tunduk terhadap peraturan tanpa menyukarkan proses pembelajaran. Cita-cita yang dimiliki siswa dalam disiplin belajar adalah mencapai sebuah prestasi yang sangat tinggi di sekolah setelah mengikuti serangkaian kegiatan proses pembelajaran.

Solihin (2017) mengemukakan bahwa perilaku yang mencerminkan disiplin belajar seperti mentaati tata tertib sekolah, mengikuti proses pembelajaran sampai selesai, memperhatikan materi yang disampaikan guru, membaca kembali materi di rumah dan mengerjakan tugas dengan tepat waktu. Hal yang mendasari siswa untuk disiplin belajar adalah kesadaran dari dalam dirinya, sehingga dengan disiplin belajar siswa dapat meningkatkan prestasi belajarnya di sekolah.

Hasil penelitian yang dilakukan oleh Haryono (2016) menyatakan bahwa peningkatan prestasi siswa bisa ditempuh dengan cara meningkatkan kedisiplinan belajar siswa secara lebih baik lagi. Sesuai dengan penelitian yang dilakukan oleh Alimaun (2015) menunjukan bahwa terdapat pengaruh yang positif dan signifikan antara kedisiplinan siswa dengan prestasi atau hasil belajar siswa di sekolah. Hal ini juga sejalan dengan penelitian yang dilakukan oleh Ma'sumah (2015) menyatakan bahwa terdapat pengaruh positif dan signifikan disiplin belajar terhadap prestasi belajar siswa.

Berdasarkan telaah pustaka dan penelitian terdahulu, maka peneliti tertarik untuk meneliti secara langsung dengan hipotesis sebagai berikut:

$\mathrm{H}_{3}$ : Disiplin Belajar Berpengaruh Positif Terhadap Prestasi Belajar Siswa Pada Mata Pelajaran Ekonomi Kelas XI IPS SMA Negeri 3 Purwokerto. 


\section{Disiplin Belajar Siswa Berpengaruh Dominan Terhadap Prestasi Belajar Siswa Pada Mata Pelajaran Ekonomi Kelas XI IPS SMA Negeri 3 Purwokerto.}

Sumantri (2010) prestasi belajar akan diraih jika siswa memiliki disiplin belajar, dengan adanya disiplin belajar siswa melaksanakan kewajiban belajar dengan sadar sehingga diperoleh perubahan pada dirinya, baik dalam hal pengetahuan, perbuatan maupun sikap baik dengan belajar di rumah atau di sekolah. Sejalan dengan Sardiman (2003:122) mengemukakan bahwa disiplin belajar adalah sebuah kunci keberhasilan bagi orang-orang yang ingin meraih kesuksesan, karena disiplin akan menciptakan kemauan untuk belajar secara lebih teratur.

Disiplin belajar merupakan faktor yang mempengaruhi prestasi belajar yang timbul dari dalam diri siswa itu sendiri, berbeda dengan pengaruh motivasi ekstrinsik dan penerapan SKS terhadap prestasi belajar dikarenakan adanya pengaruh dari luar, dalam motivasi ekstrinsik pengaruh tersebut seperti hadiah dan dalam penerapan SKS seperti optimalisasi yang dilakukan oleh pihak sekolah dalam menerapkan sistem SKS. Sehingga ketika tidak adanya hadiah atau penilaian dan juga kurang optimalnya sekolah dalam menerapkan SKS semangat siswa untuk belajar akan menurun, dikarenakan tidak adanya dorongan yang menyebabkan siswa bergerak dan berusaha untuk mendapatkan prestasi belajar yang lebih baik.

Hal ini sesuai dengan penelitian Wahid (2016) yang mengemukakan bahwa berhasil atau tidaknya penerapan SKS disebabkan oleh beberapa faktor diantaranya adalah kinerja sekolah, kesiapan sekolah dan sumber daya manusia yang dimiliki. Jika terdapat beberapa faktor dukungan keberhasilan penerapan SKS yang tidak dapat berjalankan dengan baik, maka SKS tidak akan memberikan pengaruh yang signifikan terhadap peningkatan prestasi belajar siswa.

Penelitian yang dilakukan Ma'sumah (2015) mengemukakan bahwa disiplin belajar memiliki pengaruh positif dan signifikan terhadap prestasi belajar sebesar $56,7 \%$ sedangkan $43,3 \%$ dipengaruhi oleh faktor lain yang tidak dibahas dalam penelitian. Sejalan dengan Firmansyah et al. (2015) mengemukakan bahwa terdapat pengaruh positif dan signifikan antara motivasi belajar terhadap prestasi belajar IPS dengan korelasi koefisien 0,95 serta terdapat pengaruh disiplin belajar terhadap prestasi belajar dengan koefisien korelasi 0,98.

Berdasarkan telaah pustaka dan penelitian terdahulu, maka peneliti tertarik untuk meneliti secara langsung dengan hipotesis sebagai berikut:

$\mathrm{H}_{4}$ : Disiplin Belajar Memiliki Pengaruh Yang Paling Dominan Terhadap Prestasi Belajar Siswa Pada Mata Pelajaran Ekonomi Kelas XI IPS SMA Negeri 3 Purwokerto.

\section{METODE PENELITIAN}

Jenis penelitian ini adalah penelitian kuantitatif metode survey, dengan menggunakan instrument kuisioner. Penelitian ini dilaksanakan di SMAN 3 Purwokerto semester genap tahun 
pelajaran 2018-2019. Objek Penelitian ini adalah prestasi belajar yang dipengaruhi oleh penerapan sistem kredit semester, motivasi ekstrinsik, dan disiplin belajar siswa.

Populasi dalam penelitian ini adalah siswa kelas XI IPS SMA Negeri 3 Purwokerto, dengan jumlah populasi sebanyak 175 siswa. Teknik pengambilan sampel dalam penelitian ini adalah sampel jenuh. Sugiyono (2009:122) mengemukakan bahwa sampel jenuh adalah teknik dalam menentukan jumlah sampel yang diambil dari seluruh anggota populasi, sampel dalam penelitian ini yaitu seluruh siswa kelas XI IPS sebanyak 175 siswa.

Jenis data yang digunakan berupa data primer dan data sekunder. Dalam memperoleh data untuk penelitian ini penulis menggunakan teknik kuesioner dan dokumentasi, yang digunakan untuk mendapatkan informasi terkait variabel yang digunakan yakni penerapan SKS, motivasi ekstrinsik, dan disiplin belajar. Uji instrumen terdiri dari uji instrumen kuesioner. Instrumen diuji coba untuk mengetahui validitas, reliabilitas, dengan menggunakan skala likert 1 sampai 4.

Sebelum dilakukan uji analisis data, maka data penelitian harus dilakukan uji asumsi klasik terlebih dahulu, dalam penelitian ini uji asumsi klasik meliputi uji normalitas, uji multikolinieritas, dan uji linieritas. Analisis data menggunakan analisis regresi linier berganda, uji t, uji F dan uji variable paling dominan.

\section{HASIL DAN PEMBAHASAN}

Penelitian ini dilaksanakan di SMAN 3 Purwokerto yang beralamat di Jl. Kamandaka Barat, Karang Salam, Kedungbanteng, Kabupaten Banyumas, Jawa Tengah 53152. Waktu penelitian dilaksanakan pada tanggal 29 Mei 2019, dalam penelitian ini menggunakan data primer dan data sekunder. Data primer diperoleh langsung dari siswa sebagai responden yang mengisi kuisioner. Kuisioner yang dibagikan ke responden berjumlah 175 dan setiap responden mengisi kuisioner dengan lengkap sesuai ketentuan. Data sekunder diperoleh dari guru yaitu berupa nilai rapor siswa pada mata pelajaran ekonomi SMA Negeri 3 Purwokerto tahun ajaran 2018-2019. Data primer diperoleh secara langsung melalui kusioner terkait variabel yang digunakan dalam penlitian ini, yaitu penerapan SKS, motivasi ekstrinsik, dan disiplin belajar. Variabel penerapan SKS ini terdiri dari 4 indikator yang dijabarkan menjadi 11 pernyataan. Jawaban responden dapat dilihat dari tabel 2.

Berdasarkan tabel 2 dapat dilihat jawaban responden sebanyak 64,51\% menjawab setuju dan 13,82\% tidak setuju. Adapun indikator yang digunakan dalam penelitian ini adalah peserta didik merasa senang menentukan sendiri mata pelajaran yang akan diikuti, peserta didik mengetahui kemampuan dirinya, terpacu untuk lulus lebih cepat, dan menguasai materi secara lebih mendalam 
Tabel 2. Jawaban Responden Penerapan SKS

\begin{tabular}{|c|c|c|c|c|}
\hline No. & $\begin{array}{l}\text { Skor } \\
\text { (1) }\end{array}$ & $\begin{array}{l}\text { Frekuensi } \\
(2)\end{array}$ & $\begin{array}{l}\text { Jumlah } \\
\text { (1)x(2) }\end{array}$ & $\begin{array}{c}\text { Presentase } \\
(\%)\end{array}$ \\
\hline 1. & 4 & 297 & 1188 & 21,38 \\
\hline 2. & 3 & 1195 & 3585 & 64,51 \\
\hline 3. & 2 & 384 & 768 & 13,82 \\
\hline 4. & 1 & 16 & 16 & 0,29 \\
\hline \multicolumn{2}{|c|}{$\begin{array}{l}\text { Frekuensi Jawaban } \\
\text { Paling Sering Muncul }\end{array}$} & $\begin{array}{l}1892 \\
3\end{array}$ & 5557 & 100 \\
\hline
\end{tabular}

Sumber : Data primer yang diolah tahun 2019

Variabel motivasi ekstrinsik terdiri dari 5 indikator yang dijabarkan dalam 16 pernyataan, adapun jawaban responden dapat dilihat dari table 3.

Tabel 3. Jawaban Responden Motivasi Ekstrinsik

\begin{tabular}{lllll}
\hline No. & $\begin{array}{c}\text { Skor } \\
(1)\end{array}$ & $\begin{array}{l}\text { Frekuensi } \\
(2)\end{array}$ & $\begin{array}{l}\text { Jumlah } \\
(1) \times(2)\end{array}$ & $\begin{array}{l}\text { Presentase } \\
(\%)\end{array}$ \\
\hline 1. & 4 & 939 & 3756 & 44,86 \\
2. & 3 & 1129 & 3387 & 40,45 \\
3. & 2 & 546 & 1092 & 13,04 \\
4. & 1 & 138 & 138 & 1,65 \\
\hline Total & 2752 & 8373 & 100 \\
Frekuensi Jawaban & & & \\
\multicolumn{5}{l}{ Paling Sering Muncul } \\
\multicolumn{5}{l}{ Sumber : Data primer yang diolah tahun 2019}
\end{tabular}

Berdasarkan tabel 3 dapat dilihat jawaban responden sebanyak 44,86\% menjawab selalu dan 13,04\% kadang-kadang. Adapun indikator yang digunakan dalam penelitian ini adalah pujian, persaingan dengan teman, penilaian, hadiah, dan hukuman.

Variabel disiplin belajar terdiri dari 5 indikator yang dijabarkan dalam 18 pernyataan, adapun jawaban responden dapat dilihat pada table 4 .

Tabel 4. Jawaban Responden Disiplin Belajar

\begin{tabular}{lcccc}
\hline No. & $\begin{array}{c}\text { Skor } \\
(1)\end{array}$ & $\begin{array}{c}\text { Frekuensi } \\
(2)\end{array}$ & $\begin{array}{c}\text { Jumlah } \\
(1) \times(2)\end{array}$ & $\begin{array}{c}\text { Presentase } \\
(\%)\end{array}$ \\
\hline 1. & 4 & 1217 & 4868 & 50,36 \\
2. & 3 & 1149 & 3447 & 35,66 \\
3. & 2 & 621 & 1242 & 12,85 \\
4. & 1 & 109 & 109 & 1,13 \\
\hline \multicolumn{5}{l}{ Total } \\
Frekuensi Jawaban & 43096 & 9666 & 100 \\
Paling Sering Muncul & 4 & & \\
\hline
\end{tabular}

Sumber : Data primer yang diolah tahun 2019

Berdasarkan tabel 4 dapat dilihat bahwa jawaban responden sebanyak 50,36\% menjawab selalu dan 12,85\% kadang-kadang. Adapun indikator yang digunakan dalam penelitian ini adalah peserta didik disiplin berangkat sekolah, disiplin mengikuti proses 
pembelajaran, disiplin mengerjakan tugas, disiplin belajar di rumah, dan disiplin mentaati tata tertib sekolah.

Data sekunder diperoleh dari guru yaitu berupa nilai rapor siswa pada mata pelajaran ekonomi SMA Negeri 3 Purwokerto tahun ajaran 2018-2019. Berdasarkan data nilai hasil Ujian Akhir Semester (UAS) gasal kelas XI IPS pada mata pelajaran ekonomi tahun 2018/2019 SMA Negeri 3 Purwokerto dapat diketahui bahwa nilai seluruh siswa kelas XI IPS sudah memenuhi Kriteria Ketuntasan Minimum (KKM) sebesar 70. Siswa yang memperoleh nilai dibawah batas KKM atau <70 tidak ada, siswa yang berhasil memperoleh nilai antara 70-80 sebanyak 19 siswa atau $10,86 \%$, sedangkan siswa yang memperoleh nilai $>80$ sebanyak 156 siswa atau $89,14 \%$. Hal ini membuktikan bahwa nilai UAS yang diperoleh siswa SMA Negeri 3 Purwokerto tinggi, bukan hanya sekedar mencapai ketuntasan minimum. Hal ini menunjukan bahwa SMA Negeri 3 Purwokerto telah berhasil mencapai apa yang telah ditetapkan sebagai tujuan dari pembelajaran. Dapat dilihat pada tabel 5.

Tabel 5. Responden Berdasarkan Prestasi Belajar Mata Pelajaran Ekonomi

\begin{tabular}{cllll}
\hline No. & Interval & Frekuensi & Presentase $(\%)$ & Kategori \\
\hline 1. & $<70$ & 0 & 0 & Tidak tuntas \\
2. & $70-80$ & 19 & 10,86 & Tuntas \\
3. & $>80$ & 156 & 89,14 & Tuntas \\
\hline \multicolumn{2}{l}{ Jumlah } & 175 & 100 & \\
\hline
\end{tabular}

Sumber: Nilai rapor siswa XI IPS SMAN 3 Purwokerto tahun pelajaran 2018/2019.

Selanjutnya dilakukan uji normalitas, multikolinieritas, dan linieritas. Berdasarkan hasil uji normalitas sebesar 0,079 > 0,05 menunjukkan bahwa data yang diuji berdistribusi normal. Hasil uji multikolinieritas semua variabel yaitu : nilai tolerance untuk variabel penerapan SKS, motivasi ekstrinsik, dan disiplin belajar nilainya diatas 0,10, sedangkan nilai VIF sebesar $1,083<10$ untuk variabel penerapan SKS, $1,494<10$ pada variabel motivasi ekstrinsik dan $1,414<10$ variabel disiplin belajar. Dapat diartikan bahwa antara variabel bebas tidak terjadi multikolinieritas. Sedangkan hasil uji linieritas menunjukkan terjadi linieritas karena nilai signifikansi semua variabel kurang dari 0,05 dan Deviation from linearity lebih dari 0,05. Semua data tersebut memenuhi syarat untuk dilakukan uji selanjutnya. Pengujian hipotesis menggunakan uji t, perhitungan variabel paling dominan dan analisis regresi berganda.

Berdasarkan hasil perhitungan analisis regresi dengan menggunakan bantuan program IBM SPSS 23 diperoleh persamaan regresi $Y=66,288+0,059 \mathrm{X} 1+0,136 \mathrm{X} 2+0,175 \mathrm{X} 3+\varepsilon$. Persamaan tersebut dapat diartikan bahwa koefisien regresi variabel penerapan SKS (X1) sebesar 0,059, nilai koefisien regresi yang positif. Hal ini membuktikan hubungan positif antara penerapan SKS dengan prestasi belajar, yang berarti bahwa semakin baik penerapan SKS maka semakin baik pula prestasi belajar siswa. 
Dilihat dari hasil uji secara parsial untuk variabel penerapan SKS (X1) diperoleh nilai t hitung sebesar 1,140 dengan tingkat signifikansi 0,256. Dengan derajat kebebasan t tabel : $\mathrm{n}-\mathrm{k}$ = 172-4 = 168 sebesar 1,65393. Ini berarti $\mathrm{t}$ hitung < $\mathrm{t}$ tabel, yang berarti Ho diterima dan Ha ditolak. Penelitian ini tidak sejalan dengan penelitian sebelumnya yang dilakukan oleh Moesthafa (2018) yang membuktikan bahwa terdapat pengaruh positif penerapan Sistem Kredit Semester terhadap prestasi belajar siswa, dan Zafar et al. (2014) yang mengemukakan bahwa Fully Flexible Credit System (FFCS) memiliki pengaruh yang tinggi terhadap prestasi belajar siswa. Namun, hasil penelitian ini mendukung penelitian yang dilakukan oleh Santoso (2015) yang menyatakan bahwa proses pembelajaran dengan sistem SKS berpengaruh negatif terhadap prestasi belajar siswa.

$\mathrm{H}_{1}$ : Penerapan Sistem Kredit Semester (SKS) tidak berpengaruh secara signifikan terhadap prestasi belajar ekonomi siswa kelas XI IPS SMAN 3 Purwokerto.

Koefisien regresi variabel motivasi ekstrinsik (X2) sebesar 0,136. Hal ini menunjukan bahwa hubungan antara motivasi ekstrinsik dengan prestasi belajar siswa adalah positif, sehingga semakin baik motivasi ekstrinsik siswa maka semakin baik pula prestasi belajar siswa.

Berdasarkan hasil uji t variable motivasi ekstrinsik (X2) didapat nilai t hitung sebesar 3.587 dengan tingkat signifikansi 0,000. Dengan derajat kebebasan t tabel $: n-k=172-4=168$ sebesar 1,65393. Ini berarti t hitung $>\mathrm{t}$ tabel, yang berarti Ho ditolak dan Ha diterima.

Hasil penelitian ini mendukung hasil penelitian yang dilakukan oleh Azis (2017) yang menyatakan bahwa terdapat hubungan yang positif antara motivasi ekstrinsik dan prestasi belajar siswa. Kemudian penelitian yang dilakukan oleh Octora (2013) mengemukakan bahwa motivasi ekstrinsik berpengaruh positif dan signifikan terhadap prestasi belajar mahasiswa dan penelitian yang dilakukan oleh Sahiu dan Wijaya (2017) yang mengemukakan bahwa motivasi ekstrinsik merupakan hal yang sangat penting untuk meningkatkan hasil belajar siswa, karena dengan adanya motivasi ekstrinsik siswa akan lebih aktif dan semangat dalam melaksankan proses pembelajaran sehingga siswa dapat mencapai hasil belajar yang lebih baik.

$\mathrm{H}_{2}$ : Motivasi ekstrinsik berpengaruh positif terhadap prestasi belajar ekonomi siswa kelas XI IPS SMAN 3 Purwokerto.

Koefisien regresi variabel disiplin belajar (X3) sebesar 0,175. Hal ini menunjukan bahwa hubungan antara disiplin belajar dengan prestasi belajar siswa adalah positif, sehingga semakin baik disiplin belajar siswa maka semakin baik pula prestasi belajar siswa.

Hasil uji t variabel disiplin belajar (X3) diketahui nilai $t$ hitung sebesar 3,587 dengan tingkat signifikansi 0,000. Dengan $\mathrm{t}$ tabel derajat kebebasan $: \mathrm{n}-\mathrm{k}=172-4=168$ sebesar 1,65393. Ini berarti thitung $>\mathrm{t}$ tabel, yang berarti Ho ditolak dan Ha diterima.

Hasil penelitian ini sesuai dengan Imron (2011:172) mengemukakan bahwa peserta didik yang berhasil dalam bidangnya masing-masing memiliki disiplin belajar yang tinggi, 
sebaliknya orang yang gagal meraih kesuksesan umumnya tidak disiplin hal ini terjadi karena disiplin akan menciptakan kemauan untuk belajar secara lebih teratur. Hasil penelitian ini mendukung hasil penelitian yang dilakukan oleh Haryono (2016) mengemukakan bahwa disiplin belajar merupakan cara yang dapat ditempuh siswa untuk meningkatkan prestasi belajar menjadi lebih baik lagi. Kemudian penelitian yang dilakukan oleh Alimaun (2015) menunjukan bahwa terdapat pengaruh yang positif dan signifikan antara disiplin belajar siswa dengan prestasi atau hasil belajar siswa di sekolah.

$\mathrm{H}_{3}$ : Disiplin belajar berpengaruh positif terhadap prestasi belajar ekonomi siswa kelas XI IPS SMAN 3 Purwokerto.

Disiplin belajar merupakan variable yang paling dominan terhadap prestasi belajar ekonomi siswa di uji dengan menggunakan uji variabel dominan berfungsi untuk mengetahui Sumbangan Relatif (SR) dan Sumbangan Efektif (SE) dari setiap variabel bebas terhadap variabel terikat.

Berdasarkan hasil uji variabel dominan pada tabel 20, diketahui bahwa variabel disiplin belajar memiliki nilai SR dan SE yang paling besar, yaitu SR 64,536\% dan SE 27,105\% terhadap prestasi belajar dibandingkan dengan variabel lainnya yaitu SKS dan motivasi ekstrinsik. Oleh karena itu dapat disimpulkan bahwa Ho ditolak dan Ha diterima yang berarti disiplin belajar memiliki pengaruh yang paling dominan terhadap prestasi belajar siswa.

Hasil penelitian ini mendukung hasil penelitian yang dilakukan oleh Sumantri (2010) mengemukakan bahwa disiplin belajar merupakan kunci keberhasilan dalam meraih prestasi belajar siswa di sekolah. Kemudian penelitian yang dilakukan oleh Ma'sumah (2015) menyatakan bahwa disiplin belajar memiliki pengaruh yang positif dan signifikan terhadap prestasi belajar siswa sebesar $56,7 \%$, sedangkan variabel lainnya hanya $43,3 \%$.

$\mathrm{H}_{4}$ : Disiplin belajar memiliki pengaruh yang paling dominan terhadap prestasi belajar ekonomi siswa kelas XI IPS SMAN 3 Purwokerto.

\section{KESIMPULAN}

Berdasarkan hasil penelitian yang telah dilakukan, maka dapat diambil kesimpulan sebagai berikut: Penerapan Sistem Kredit Semester (SKS) tidak berpengaruh secara signifikan terhadap prestasi belajar ekonomi siswa kelas XI IPS SMAN 3 Purwokerto. Tidak berpengaruhnya variabel ini dapat disebabkan oleh beberapa hal diantaranya disebabkan karena SKS belum diterapkan secara maksimal, dan adanya salah satu faktor penerapan sistem pembelajaran SKS yang belum dijalankan di SMAN 3 Purwokerto yaitu moving class. Motivasi ekstrinsik berpengaruh positif terhadap prestasi belajar ekonomi siswa kelas XI IPS SMAN 3 Purwokerto. Hal ini menunjukan bahwa semakin baik motivasi ekstrinsik yang dimiliki siswa, maka semakin baik pula prestasi belajar yang akan diperoleh siswa. Disiplin belajar 
berpengaruh positif terhadap prestasi belajar ekonomi siswa kelas XI IPS SMAN 3 Purwokerto. Hal ini menunjukan bahwa semakin baik disiplin belajar siswa, maka semakin baik pula prestasi belajar yang akan diperoleh siswa. Disiplin belajar memiliki pengaruh yang paling dominan terhadap prestasi belajar ekonomi siswa kelas XI IPS SMAN 3 Purwokerto. Berdasarkan hasil uji variabel dominan, disiplin belajar memiliki nilai SR sebesar $64,536 \%$ dan nilai SE sebesar $27,105 \%$.

Pihak sekolah sebaiknya meninjau kembali keefektifan sistem pembelajaran dengan menggunakan Sistem Kredit Semester (SKS) dan menerapkan sistem moving class di SMAN 3 Purwokerto, sehingga sistem SKS dapat memaksimalkan fungsinya untuk mengeksplor kemampuan yang dimiliki siswa sehingga dapat meningkatkan prestasi belajar siswa. Guru diharapkan dapat meningkatkan semangat belajar siswa melalui motivasi ekstrinsik khususnya dengan memberikan penilaian yang tinggi, sehingga terciptanya proses pembelajaran yang lebih aktif dan dapat meningkatkan prestasi belajar siswa. Selain itu, guru juga harus lebih tegas terhadap siswa yang mengganggu berlangsungnya proses pembelajaran di kelas. Siswa diharapkan dapat belajar secara lebih optimal, dengan memiliki motivasi ekstrinsik dan disiplin belajar yang tinggi. Siswa diharapkan mampu mengikuti proses pembelajaran dengan lebih semangat dan dapat meningkatkan disiplin belajar di rumah dengan mempelajari kembali materi yang diajarkan guru di sekolah sehingga prestasi belajar akan meningkat. Hasil dari penelitian ini diharapkan dapat menjadi salah satu bahan pertimbangan pada penelitian selanjutnya dan diharapkan dapat menambah variabel lain yang dapat mempengaruhi prestasi belajar, misalnya pengaruh penerapan moving class dan metode pembelajaran yang diterapkan guru.

\section{DAFTAR PUSTAKA}

Aini, Qurattul. 2016. Pengaruh Motivasi Intrinsik Dan Ekstrinsik Terhadap Prestasi Belajar Ekonomi Di SMA NW Pancor Lombok Timur NTB. Jurnal Ganec Swara, Vol 10. No. 2.

Alimaaun, Imam. 2015. Pengaruh Kedisiplinan Terhadap Hasil Belajar Siswa Kelas V Sekolah Dasar Sedaerah Binaan R.A Kartini Kecamatan Kutoarjo Kabupaten Purworejo. Skripsi. Universitas Negeri Semarang.

Anjarsari, Trisna Dwi. 2017. Sistem SKS Untuk Meningkatkan Prestasi Peserta Didik Pada Mata Pelajaran Fiqih Kelas XI MIA 1 Di MAN Tulungagung. Skripsi. IAIN Tulungagung.

Anwar, Laraswati Aridne. (2018, Juli 10). Pola Satuan Kredit Semester Kian Diminati. Kompas Online. Diakses dari http://www.kompas.id.

Aunurrahman. 2010. Belajar dan Pembelajaran. Bandung: Alfabeta.

Arifin. Zainal. 2013. Evaluasi Pembelajaran. Bandung: PT. Remaja Rosdakarya. 
Azis, Ayu Lestari. 2017. Pengaruh Motivasi Intrinsik dan Motivasi Ekstrinsik Terhadap Prestasi Belajar Ekonomi Bisnis Kelas X di SMK N 4 Makassar. Tesis. Universitas Negeri Makassar.

Badan Standar Nasional Pendidikan. 2005. Peraturan pemerintah No. 15 Tahun 2005. tentang Standar Nasional Pendidikan telah menyusun panduan penyelenggaraan SKS. . 2010. Panduan Penyelenggaraan Sistem Kredit Semester. Jakarta : Badan Standar Nasional Pendidikan.

Blegur, Jusuf., Manu dan Souisa. 2018. Students Disciplined Character as the Effort to Improve SelfEsteem and Academic Performance. International Journal of Academic Research in Business and Social Sciences, 8(4), 366-367. Doi: 10.6007/IJARBSS/v8-i4/4019.

Dariyo, Agoes. 2013. Dasar-dasar Pedagogi Modern. Jakarta: PT. Indeks.

Fatmawati, Endah Tri. 2012. Pengaruh Motivasi Ekstrinsik Dan Disiplin Belajar Terhadap Prestasi Belajar Peserta Didik Kelas VI Sekolah Dasar Negeri Sidorejo Lor 03 Salatiga. Skripsi. Universitas Kristen Satya Wacana Salatiga.

Firmansyah, Djasmi dan Jaya. 2015. Pengaruh Motivasi Belajar Dan Disiplin Belajar Terhadap Prestasi IPS Siswa. Jurnal Skripsi. Universitas Lampung.

Hamalik, Oemar. 2008. Proses Belajar Mengajar. Jakarta: PT. Bumi Aksara.

Hardini, Agustina Tyas Asri. 2016. Evaluasi Program Sistem Kredit Semester Di SMA Negeri 1 Salatiga. Jurnal Manajemen Pendidikan, Vol 3. No. 2.

Haryono, Sugeng. 2016. Pengaruh Kedisiplinan Siswa Dan Motivasi Belajar Terhadap Prestasi Belajar Siswa Pada Mata Pelajaran Ekonomi. Jurnal Ilmiah Kependidikan, Vol 3. No. 3.

Hasbullah. 2013. Dasar-Dasar Ilmu Pendidikan. Jakarta: Rajawali Pers.

Imron, Ali. 2011. Manajemen Peserta Didik Berbasis Sekolah. Jakarta. PT. Bumi Aksara.

Ma'sumah, Siti. 2015. Pengaruh Disiplin Belajar Terhadap Prestasi Belajar Siswa Kelas IV Sekolah Dasar Negeri Se-Daerah Binaan II Kecamatan Pertahanan Kabupaten Kebumen. Skripsi. Universitas Negeri Semarang.

Moesthafa, Indra. 2018. Manajemen Kurikulum Sistem Kredit Semester Dalam Meningkatkan Prestasi Belajar Siswa Di SMA Negeri 1 Probolinggo. Tesis. UIN Maulana Malik Ibrahim Malang.

Muhlis, Achmad. 2017. Pengembangan Pembelajaran Dengan Sistem Kredit Semester Di MTS Negeri Sumber Bungur Pamekasan. Disertasi. Universitas Muhamadiyah Malang.

Mulyasana, Dedi. 2012. Pendidikan Bermutu dan Berdaya Saing. Bandung: PT. Remaja Rosdakarya Offset.

Octora, Sandra Endang Suci. 2013. Pengaruh Motivasi Ekstrinsik Dan Intrinsik Terhadap Prestasi Belajar Mahasiswa Program Studi Manajemen Perkantoran Pada Akademi Sekertariat Dan Manajemen Widya Dharma Pontianak. Jurnal Manajemen Bisnis, Vol 1. NO.1.

OECD. 2016. Programme For International Students Assesment. Diakses 2 Mei 2019, dari OECD Database. 
Sahiu dan Wijaya. 2017. Hubungan Motivasi Belajar Ekstrinsik Terhadap Hasil Belajar Psikomotorik Pada Mata Pelajaran Kristen Kelas V Di SDN Zion Makassar. Jurnal Jaffray, Vol 15. No. 2. Santoso, Arif Bayu. 2015. Pendidikan Berbasis SKS Dalam Meningkatkan Prestasi Akademik Siswa Kelas SCI (Siswa Cerdas Istimewa). Program Studi Pendidikan Islam UIN Sunan Kalijaga. Santrock, John W. 2011. Psikologi Pendidikan. Jakarta: Prenada Media Grup. Sardiman. 2007. Interaksi dan Motivasi Belajar Mengajar. Jakarta: PT. Raja Grafindo Persada. Sari, Suarman, dan Trisnawati. 2017. Pengaruh Motivasi dan Disiplin Belajar Terhadap Prestasi Belajar Siswa Pada Mata Pelajaran IPS di SMPN 13 Pekanbaru. Jurnal Keguruan Dan Ilmu Pendidikan, Vol 4. No 1.

Schroeder, Harold. 2012. The Importance Of Human Resource Managemrnt In Strategic Sustinability: An Art And Science Perspective. Journal Of Environmental Sustanibility, Vol 2. Issue. 2.

Setyaningrum, Istriyana. 2011. Hubungan Disiplin Belajar Dan Motivasi Belajar Dengan Prestasi Belajar IPA Siswa Kelas V SD Negeri Gugus Lokantara. Skripsi. Universitas Kristen Satya Wacana.

Slameto. 2010. Belajar dan Faktor-faktor Yang Mempengaruhinya. Jakarta: PT. Rineka Cipta.

Solihin. 2017. Pengaruh Kedisiplinan Terhadap Prestasi Siswa SMAN 1 Benai Kabupaten Kuantang Singgigi. Jom Fisip, Vol 4. No. 1.

Sriyono, Heru. 2017. Learning Discipline on Social Science Achievement at Junior High School in Bekasi, West Java Province, Indonesia. International Journal of Sciences: Basic and Applied Research, Vol 32. No.3.

Sugiyono. 2009. Metode Penelitian Bisnis. Bandung: Alfabeta.

Sumantri, Bambang. 2010. Pengaruh Disiplin Belajar Terhadap Prestasi Belajar Siswa Kelas XI SMK PGRI 4 Ngawi Tahun Pelajaran 2009/2010. Jurnal, Vol VI. No. 3.

Suryabrata, Sumadi. 2014. Psikologi Pendidikan. Jakarta: PT. Raja Grafindo Persada.

Tirtonegoro, Sutratinah. 2006. Anak Supernormal dan Program Pendidikannya. Jakarta: PT. Bumi Aksara.

Uno, Hamzah B. 2009. Perencanaan Pembelajaran. Jakarta: Bumi Aksara.

Yoga, I Gusti Agung., Rackhman, Masrukhi and Hardyanto. 2016. Developing A Model Of Learning Management Of The Semester Credit System In Magelang Military Academi. The Journal of Education Development, Vol 4. No. 1.

Zafar, S., Manjurekar., Kumar, P., and Khan, Zaved. 2014. Effects Of FFCS On Learning Experience And Academic Performance. Procedia Social And Behavioral Sciences, 143 (2014) 4-7. Doi: 10.1016/j.sbspro.2014.07.347. 